\title{
Covid 19, the Kerala experience: an observational, single centre retrospective study of outcome in covid positive pregnancies
}

\author{
Sabnam S. Nambiar*, Ajith S., Reshmi V. P. \\ Department of Obstetrics and Gynecology, Government Medical College, Kannur, Kerala, India \\ Received: 10 June 2020 \\ Accepted: 08 July 2020

\section{*Correspondence:} \\ Dr. Sabnam S. Nambiar, \\ E-mail: sabnamsn@rediffmail.com \\ Copyright: (C) the author(s), publisher and licensee Medip Academy. This is an open-access article distributed under \\ the terms of the Creative Commons Attribution Non-Commercial License, which permits unrestricted non-commercial \\ use, distribution, and reproduction in any medium, provided the original work is properly cited.
}

\begin{abstract}
Background: Covid 19 has spread across the world at an alarming rate. Approximately 4.05 million people have got infected worldwide resulting in around 279,000 deaths. Over 1 million people have recovered worldwide. Aim of this study was to determine whether course and severity of covid 19 is altered in pregnant women and whether covid 19 seemed to worsen the prognosis in pregnant women.

Methods: Around 50 covid positive patients were admitted to this study hospital, a tertiary care referral hospital and medical college, between march and May 2020, 11 were pregnant. Authors collected their data retrospectively to understand the course of their disease till the period of recovery.

Results: There were 6 patients above 31 weeks of whom one had elective repeat caesarean section, one had full term vaginal delivery, one is under follow up. Three patients had foetal distress necessitating emergency caesarean section. Of the remaining 5 patients with periods of gestation between 9-13 weeks, 1 of 24 weeks, 6 patients above 31 weeks, one had a miscarriage. Rest pregnancies are continuing and under follow up. 6 women had been symptomatic at admission, with mild symptoms of low-grade fever, sore throat and rhinitis. All were treated with hydroxychloroquine (HCQs). Those with respiratory symptoms like cough were also treated with oseltamivir. In view of high prevalence of $\mathrm{H} 1 \mathrm{~N} 1$ in the region. None of the women developed severe disease. The disease did not appear to worsen prognosis in pregnant women. The rate of recovery in pregnant women was similar to that seen in non-pregnant women and also men under the age of 40 years admitted in this study hospital.

Conclusions: Covid 19 did not seem to worsen the prognosis in pregnant individuals when compared to rest of the population. The foetal outcomes also seemed favorable. However larger studies are required before concrete guidelines could be formulated for management of the disease in pregnancy.
\end{abstract}

Keywords: Caesarean section, Covid 19, Pregnancy, Hydroxychloroquine, Miscarriages, Reverse transcription polymerase chain reaction

\section{INTRODUCTION}

Covid 19 is a pandemic which has caught the world by surprise and within a span of days established a vice like grip over countries worldwide no nation has been spared. The mortality and morbidity rates continue to rise daily. India, though, has not been vastly affected. Being a diverse people, different states have responded differently. Although authors took the bold step of a lockdown at quite an early stage, some states have fared better than the rest one such state is the south Indian state of Kerala. This small state with a population of 34.8 million, accounts for $2.76 \%$ of Indian population, 859 persons per sq $\mathrm{km} .{ }^{1}$ This state has managed to limit its disease numbers to 500 with only 4 deaths till date. By May 2 Kerala had 498 cases of which an astounding $78 \%$ or 392 cases have recovered.

Authors medical college hospital is a designated covid centre in northern Kerala, one of the hotspots. Till date 
authors have had nearly 50 odd cases admitted in this hospital of which all have been cured and discharged. There was one death and covid suspects continue to being admitted. This approximately resembles the overall pattern in Kerala.

This is quite the baffling disease which becomes all the more difficult if a pregnancy is involved.

Corona virus or covid 19 is caused by coronavirus 2 (SARS-cov2) which causes severe acute respiratory syndrome. $^{2}$ It was initially identified in a wet market in Wuhan, china, then spread globally like wildfire. ${ }^{3,4}$ It usually presents with fever, cough, breathlessness, anosmia, diarrhoea. ${ }^{5,6}$ Some cases may progress to pneumonia, multiorgan dysfunction and cytokine storm. ${ }^{3,7,8}$ The duration from exposure to onset of symptoms is around two to fourteen days. ${ }^{4,9}$ It has a droplet spread during coughing, sneezing, etc. the droplets may either remain airborne or fall on the ground. They last for varied amount of time on different surfaces. ${ }^{10-12}$ They can then spread when a person after touching a contaminated surface touches their face.

It can be detected on oropharyngeal or nasopharyngeal swab by real time polymerase chain reaction(rt-PCR). ${ }^{13}$ CT may also be helpful in symptomatic patients but is not routinely recommended. ${ }^{14,15}$

Frequent washing of hands and face, maintaining social distancing, quarantine, covering face while coughing or sneezing, wearing face masks can help in preventing dissemination of the disease. ${ }^{16-19}$

The disease chiefly affects the lungs .it has been found that the virus uses angiotensin converting enzyme 2 (ACE2), most abundantly found in the alveolar cells of the lungs. the virus has a surface glycoprotein or spike protein which connects to ACE2 to enter the cell. ${ }^{20}$ Hence it has been postulated that decreasing ACE2 activity might be protective..$^{21,22}$

However, studies have also shown that disease severity increase is a result of virus induced deficiency of ACE2 as seen in elderly and diseased persons. This deficiency may magnify the dysregulation between adverse ACEangiotensin II-AT1 receptor axis and the protective ACE2-angiotensin 1-7-Mas receptor axis. In the lungs this might cause progressive inflammatory and thrombotic processes triggered by local angiotensin II hyperactivity unopposed by angiotensin $1-7 .{ }^{23}$

Pregnancy by itself also induces a deficiency of ACE2. ${ }^{24}$ Hence there is fear that the additional ACE2 deficiency induced by the virus may aggravate the damage due to the virus. Pregnancy is also a state of reduced cell mediated immunity, hence there is possibility of increased viral activity in pregnancy.
Largely the course of the disease has been found to be milder in pregnant women in most case series from across the globe. However there have been some reports especially from some Chinese studies stating the probable increase in abnormal foetal heart rate patterns, foetal distress, miscarriages and adverse obstetric outcome. ${ }^{25}$ Hence large-scale studies are required to present the actual picture of the disease in pregnancy.

Treatment comprises antipyretics, intravenous fluid therapy, oxygen, etc. Paracetamol is recommended for control of temperature. ${ }^{26}$ Low molecular weight heparin has been suggested in people showing coagulopathy. ${ }^{27}$ Other drugs being studies are hydroxychloroquine, oseltamivir, remdesivir, etc. Disease rates have been found to be lesser in countries where BCG vaccination is mandatory.

Severe cases may require mechanical ventilation. ${ }^{28,29}$

There is limited data available regarding the course of the disease in pregnancy. Due to the decreased cellular immunity pregnant women may be more susceptible to many viral diseases. Being in quarantine could take a large physical and mental toll on the patient. At present there are no definite guidelines on antepartum and intrapartum management of covid patients. Research is underway all around the world.

Here authors have attempted to present the course of the disease and how it was managed among the pregnant covid patients admitted to this study hospital.

\section{METHODS}

Around 50 patients who tested covid positive patients were admitted to the study hospital which is a tertiary care referral hospital and medical college, between the months of March 2020 and May 2020, of which 12 patients were pregnant. Authors have taken their data and observed the course of their disease and followed them up till the period of recovery.

The parameters authors observed were as follows.

- $\quad$ Age of patient

- Period of gestation

- Symptoms and severity

- After how many days of exposure patient developed symptoms

- Was diagnosis established on $1^{\text {st }}$ test

- Were repeat tests needed, if so why

- Interval of symptoms to testing

- Sample-nasopharyngeal/oropharyngeal

- Interval from test to diagnosis

- Time taken for test to become negative

- Abnormal blood investigations if any

- Duration of symptoms

- Treatment place/change of place/change in treatment 
- Outcome

- Resolved in how many days

- Required obstetric intervention

- Mode of delivery

- Induction if required

- Indication of caesarean

- Obstetric complications

- Needed blood or blood products

- Needed higher antibiotics

- Any other medications, oxygen/steroids

- Mental health issues

- Neonatal outcome
- Any other special investigations

Authors followed their outcome and course of the disease based on these parameters. They were compared with course of the disease, disease severity and outcome in male and nonpregnant female positive covid patients below 40 years. strict confidentiality was maintained during collection and analysis of data.

\section{RESULTS}

All the 12 positive patients belonged to the age group of 20-30 years.

Table 1: Patient details.

\begin{tabular}{|c|c|c|c|c|c|c|c|c|}
\hline$\stackrel{B}{E}$ & 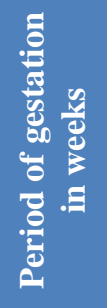 & $\begin{array}{l}\text { है } \\
\text { है } \\
\text { है } \\
\text { ह }\end{array}$ & 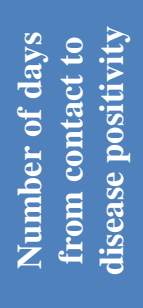 & 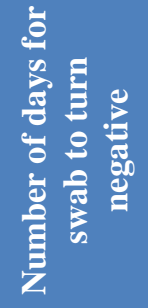 & 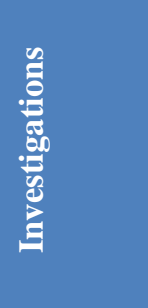 & $\begin{array}{l}\stackrel{\mathscr{E}}{8} \\
\stackrel{3}{\Xi} \\
0\end{array}$ & 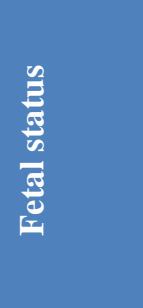 & 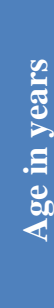 \\
\hline Primi & 37 & $\begin{array}{l}\text { Fever, mild } \\
\text { headache }\end{array}$ & 3 & 7 & Normal & $\begin{array}{l}\text { Emergency } \\
\text { caesarean, MSAF, } \\
\text { fetal tachycardia }\end{array}$ & Negative & 29 \\
\hline G2p111 & 13 & Asymptomatic & 7 & 4 & Normal & $\begin{array}{l}\text { USG normal, } \\
\text { follow-up }\end{array}$ & - & 22 \\
\hline G2p111 & 31 & $\begin{array}{l}\text { Fever, sore } \\
\text { throat }\end{array}$ & 5 & 5 & $\begin{array}{l}\text { Left } \\
\text { abnormal }\end{array}$ & FTND at 39 weeks & Negative & 26 \\
\hline Primi & 13 & Fever, cough & 3 & 9 & Normal & $\begin{array}{l}\text { USG normal, } \\
\text { follow-up }\end{array}$ & - & 23 \\
\hline G3p212 & 9 & $\begin{array}{l}\text { Headache, } \\
\text { rhinitis }\end{array}$ & 5 & 7 & Normal & $\begin{array}{l}\text { USG normal, } \\
\text { follow-up }\end{array}$ & - & 24 \\
\hline G3p212 & 36 & Asymptomatic & 9 & 6 & Normal & $\begin{array}{l}\text { Elective repeat } \\
\text { LSCS at } 38 \text { weeks }\end{array}$ & Negative & 26 \\
\hline G3p111a1 & 9 & Asymptomatic & 10 & 5 & Normal & $\begin{array}{l}\text { USG normal, } \\
\text { follow-up }\end{array}$ & - & 24 \\
\hline Primi & 31 & Asymptomatic & 9 & 6 & Normal & FTND at 39 weeks & - & 21 \\
\hline G3p111a1 & 12 & $\begin{array}{l}\text { Bleeding per } \\
\text { vaginum }\end{array}$ & 7 & 4 & Normal & Miscarriage & - & 20 \\
\hline Primi & 35 & Asymptomatic & 6 & 4 & Normal & $\begin{array}{l}\text { Emergency } \\
\text { caesarean, fetal } \\
\text { distress }\end{array}$ & Normal & 21 \\
\hline Primi & 24 & Fever, rhinitis & 5 & 5 & Normal & $\begin{array}{l}\text { USG normal, } \\
\text { follow-up }\end{array}$ & - & 26 \\
\hline G2p111 & 37 & asymptomatic & 4 & 7 & Normal & $\begin{array}{l}\text { Emergency } \\
\text { caesarean, severe } \\
\text { foetal bradycardia }\end{array}$ & Normal & 28 \\
\hline
\end{tabular}

FTND: full term normal delivery, USG: ultrasonogram.

A total 6 of them were above 31 weeks of gestation, 5 belonged to 9-13 weeks of gestation, and one was of 24 weeks. 5 patients were asymptomatic and detected on testing done on suspects with contact history with gulf returned expatriates. The remaining 6 presented only with mild fever and cough. They were admitted, kept under isolation. Fever was treated with paracetamol. 
Hydroxychloroquine was started for all patients. Those with respiratory symptoms were treated with oseltamivir.

All patients were contacts of expatriates returned from gulf countries.

A total 7 were multigravida and 5 were primigravida.

All became seropositive within 5-14 days of contact with index case (Table 2) RT-PCR on nasopharyngeal swab was used for the diagnosis. All patients except one $(90.9 \%)$ were detected to be positive by the first test. The one exception was detected to be positive by a second test repeated after three days of the first test (Table 1).

All the symptomatic patients had resolution of symptoms within 2-3 days. Within 4-9 days they tested negative for the virus, following which they were observed in the hospital for another week. Another swab was usually repeated after the first negative test after 3 days.

Of the six patients beyond 31 weeks after attaining seronegative, one on foetal assessment showed foetal distress (meconium stained amniotic fluid and tachycardia) for which emergency lower segment caesarean section (LSCS) was done. Another patient at 37 weeks developed severe foetal bradycardia detected on routine NST for whom emergency caesarean section was done. These may be considered as an adverse event in this scenario. Whether the distress was secondary to the effect of the virus remains to be corroborated with tests done on larger samples.

The fourth patient underwent elective repeat LSCS after 38 completed weeks.

The remaining two patient admitted initially at 31 weeks and discharged after cure, developed spontaneous labour pains after 39 weeks and underwent normal vaginal delivery.

All of these neonates tested negative, along with negative amniotic fluid and breast milk. Amniotic fluid specimens were taken for rt-PCR which returned negative. Breast milk samples and oropharyngeal swab of the neonates were also negative for Covid 19.

Of the remaining, 5 patients between 9-13 weeks gestation, one had presented with bleeding in addition, diagnosed as a case of missed abortion and was managed medically. The rest had healthy ongoing pregnancies at discharge and are under follow-up. Whether the miscarriage was due to the virus or otherwise, is a pertinent question.

One patient admitted at 24 weeks is presently asymptomatic, ultrasonogram was normal, and she is under follow-up.
There was abnormal liver function test in one patient $(9.09 \%)$, rest investigations being within normal limits.

All other patients had normal blood parameters.

None of the patients developed severe disease. None required transfusion of blood or blood products.

A total 4 of the 11 patients $(27.27 \%)$ developed adverse effects in the form of meconium stained amniotic fluid/fetal distress and miscarriage. Whether it was a result of the disease or independent of it needs larger studies for confirmation.

Like the nonpregnant women and men under 40 years of age, the outcome and prognosis were not found to be worse in pregnant patients. However, none of the patients below 40 years including men and nonpregnant women admitted in the study hospital had developed critical disease. The time of onset of disease was found to be on an average of 3 days to 2 weeks, and seronegative was achieved between 3-10 days on average. Hence pregnancy did not seem to worsen the outcome (Table 2).

Table 2: Outcome.

\begin{tabular}{|llll|}
\hline \multirow{2}{*}{ Parity } & \multicolumn{3}{c}{ n (\%) } \\
\hline \multirow{3}{*}{ Symptoms } & Primi & 5 & $41.66 \%$ \\
\cline { 2 - 4 } & Multi & 7 & $58.33 \%$ \\
\cline { 2 - 4 } & Asymptomatic & 6 & $50 \%$ \\
\cline { 2 - 4 } & Mild & 6 & $50 \%$ \\
\hline $\begin{array}{l}\text { Moderate/ } \\
\text { Severe }\end{array}$ & - & - \\
\hline $\begin{array}{l}\text { Number of days from } \\
\text { contact to positive } \\
\text { diagnosis }\end{array}$ & $<7$ & 7 & $58.33 \%$ \\
\hline $\begin{array}{l}\text { Number of days for } \\
\text { swab to turn negative }\end{array}$ & $7-14$ & 5 & $41.66 \%$ \\
\cline { 2 - 4 } & $<-14$ & 8 & $66.66 \%$ \\
\hline
\end{tabular}

\section{DISCUSSION}

Corona virus or covid 19 is a type of severe acute respiratory syndrome corona virus (SARS-COV 2). It is a highly infectious disease which has spread across the world at quite an alarming rate. Approximately 4.05 million people have got infected with the virus worldwide, and has resulted in around 279,000 deaths. Over 1 million people have recovered worldwide. ${ }^{30}$ It usually presents with respiratory symptoms.

Treatment comprises antipyretics, intravenous fluid therapy, oxygen, etc., paracetamol is recommended for control of temperature. ${ }^{26}$ Low molecular weight heparin has been suggested in people showing coagulopathy. ${ }^{27}$ Other drugs being studied are hydroxychloroquine, oseltamivir, remdesivir, etc. Disease rates have been found to be lesser in countries where BCG vaccination is mandatory. 
The disease has been found to have a higher incidence and severity in men when compared to women worldwide. This could be due to lack of oestrogen which helps protect women against many chronic diseases. elderly patients $(\geq 65$ years old), were more likely to develop severe form of the disease. Men tended to develop more serious illness than women. It was also found that mortality was also higher in the elderly. According to studies in china the number of men was found to be 2.4 times that of women in the deceased patients. While men and women had similar susceptibility, men were at higher risk of dying. ${ }^{36}$

The course of the disease has been found to be milder in pregnant women in most case series from across the globe. Pregnancy is a condition with decreased cell mediated immunity, hence there are fears of the disease worsening. However, studies have also shown a reduced concentration of Angiotensin converting enzyme levels in pregnancy. Consequently, this could correlate with reduced ACE receptor expression on cells as ACE receptors are found to be the primary site where virus binds to the cell. However there have been some reports especially from some Chinese studies stating the probable increase in abnormal foetal heart rate patterns, foetal distress, miscarriages and adverse obstetric outcome. ${ }^{25}$

Chloroquine is a drug used for treatment of malaria which is common in tropical countries.it has antiinflammatory and antiviral actions in addition to antimalarial action. Chloroquine is found to increase endosomal $\mathrm{pH}$ and it also prevents glycosylation of SARS COV 2 cellular receptors; thus, it may have a role in blocking the disease onset. ${ }^{31}$ Chloroquine inhibits quinone reductase-2, involved in sialic acid biosynthesis making it a broadspectrum antiviral agent. Human coronavirus $\mathrm{HCoV}-\mathrm{O} 43$ requires sialic acid moieties as receptor. Chloroquine also inhibits cathepsins, causing formation of autophagosome which cleaves SARS-CoV2 spike protein. Chloroquine inhibits MAP-kinase thus interfering with SARS-CoV-2 molecular crosstalk, while causing alteration of virion assembly, budding with simultaneous interference with proteolytic processing of M protein. ${ }^{32,33}$

Studies demonstrate that chloroquine has potent antiSARS-CoV-1 effects in vitro, due to lack of glycosylation receptors at the viral cell surface, thus preventing it from binding to angiotensin-converting enzyme 2 (ACE2) receptor in lung, heart, kidney and intestine. SARS-CoV-2 uses similar surface receptor ACE2, hence possible that chloroquine may also interfere with ACE2 receptor glycosylation preventing SARSCoV-2 attachment to the target cells. ${ }^{31-34}$ In-vitro studies demonstrate effectiveness of chloroquine in reducing viral replication with standard dosing due to good tissue penetration in the lungs. ${ }^{33,35}$

Hydroxychloroquine which is structurally and functionally similar to chloroquine has a narrow therapeutic and safety index margin with chloroquine making HCQ a safer option than chloroquine.

HCQ also decreases production of pro-inflammatory markers and cytokines making it a disease modifying anti-inflammatory agent in the treatment of various autoimmune diseases including rheumatoid arthritis and systemic lupus erythematosus. the clinical safety of HCQ is found to be better than that of chloroquine, thus allowing higher daily dose of HCQ with minimal drugdrug interactions.

H1N1 influenza is also common in this part of the country, hence respiratory symptoms may mimic those of corona. Addition of oseltamivir can help alleviate symptoms of influenza.

As per the ministry of health and family affairs bulletin retrieved on $10^{\text {th }}$ May 2020, the total number of active cases is 80,$000 ; 60,000$ people have been cured and discharged. 6000 people have succumbed to the disease till date.

In the densely populated Indian state of Kerala there were 800 infected people of whom 500 were cured. There were 4 deaths attributed to the disease. These are impressive numbers when compared to other Indian states and worldwide. Notwithstanding its limitations the state has managed to achieve these numbers through a disciplined lifestyle, strict adherence to lockdown, stringent testing, contact tracing and a very efficient sociopolitical machinery. The diet in this part of the country, consisting predominantly of rice, sea food, leafy and root vegetables, could also be a reason for the decreased morbidity and mortality rates in this state.

The disease has been found to have a higher incidence and severity in men when compared to women worldwide. This could be due to lack of oestrogen which helps protect women against many chronic diseases. elderly patients $(\geq 65$ years old), were more likely to develop severe form of the disease. Men tended to develop more serious illness than women. It was also found that mortality was also higher in the elderly. According to studies in china the number of men was found to be 2.4 times that of women in the deceased patients. While men and women had similar susceptibility, men were at higher risk of dying. ${ }^{36}$

\section{CONCLUSION}

Covid 19 is an emerging disease, which needs dedicated studies to unravel its mysteries in this small study authors could find no difference in relation to onset of disease, cure rates or severity in pregnant women when compared to nonpregnant women and healthy men of similar age groups. Pregnancy does not seem to worsen the course or prognosis of the disease. Foetal outcomes also did not seem to worsen. However, the small number of cases in this study could be deemed its limitation. Larger 
multicentric data are needed if a clearer picture of the disease has to be achieved.

Funding: No funding sources Conflict of interest: None declared

Ethical approval: The study was approved by the Institutional Ethics Committee

\section{REFERENCES}

1. Census of India: provisional population totals India: paper 1: census 2011, census India. 2011. Available at: https://censusindia.gov.in/2011-provresults/prov_results_paper1_india.html. Accessed on 16 April 2020.

2. Corona virus disease 2019 (covid 19) - symptoms and causes. Mayo Clinic. Available at: https://www.mayoclinic.org/diseases-

conditions/coronavirus/symptoms-causes/syc-

20479963. Accessed on 14 April 2020.

3. Hui DS, Azhar E, Madani TA, Ntoumi, Kock R, Dar O, et al. The continuing 2019-nCoV epidemic threat of novel coronaviruses to global health: the latest 2019 novel coronavirus outbreak in Wuhan China. Int J Infect Dis. 2020;91:264-6.

4. WHO Director general's opening remarks at the media briefing on covid 19 . World health organization press release. Accessed 12 March 2020.

5. Symptoms of corona virus. U S Centre for disease control and prevention (CDC). Available at: https://www.cdc.gov/coronavirus/2019-

ncov/symptoms-testing/symptoms.html. Accessed on 14 April 2020.

6. Q and A on corona virus (covid 19). World health organization archived from the original. https://www.who.int/dg/speeches/detail/who-

director-general-s-opening-remarks-at-the-mediabriefing-on-covid-19---11-march-2020. Accessed on 11 March 2020.

7. Hopkins, Claire. Loss of sense of smell as marker of covid 19 infection. Ear, nose and throat. Surgery body of unitedkingdom. Available at: https://www.entuk.org/sites/default/files/files/Loss\% 20of\%20sense $\% 20$ of $\% 20$ smell $\% 20$ as $\% 20$ marker $\% 2$ 0of\%20COVID.pdf. Accessed on 16 April 2020.

8. Mehta P, McAuley DF, Brown M, Sanchez E, Tattersall RS, Manson JJ. HLH Across Speciality Collaboration. COVID-19: consider cytokine storm syndromes and immunosuppression. Lancet (London, England). 2020;395(10229):1033.

9. $\mathrm{Q}$ and $\mathrm{A}$ on coronaviruses. World health organization (who) archived from the original on 20 Jan 2020. Available at: https://www.who.int/newsroom/detail/27-04-2020-who-timeline---covid-19. Accessed 16 April 2020.

10. Velavan TP, Meyer CG. The COVID-19 epidemic. Trop Med Inter Health. 2020;25(3):278.

11. Q and A on CORONA VIRUS(COVID-19).World Health Organization. Accessed 14 May 2020.
12. Centers for Disease Control and Prevention (CDC). 2 April 2020. How COVID-19 Spreads. Available at: https://www.researchgate.net/publication/342898659 _COVID-19_and_Its_Effect_on_Education_System. Accessed on 16 April 2020.

13. European Centre for Disease Prevention and Control. $\mathrm{Q}$ and A on COVID-19. Available at: https://www.who.int/reproductivehealth/publications /emergencies/COVID-19-SRH/en/. Accessed on 30 April 2020.

14. Centers for Disease Control and Prevention (CDC). 11 February 2020. Interim Guidelines for Collecting, Handling, and Testing Clinical Specimens from Persons for Coronavirus Disease 2019 (COVID-19). Available at: https://www.cdc.gov/coronavirus/2019ncov/lab/lab-biosafety-guidelines.html. Accessed on 26 March 2020.

15. Salehi S, Abedi A, Balakrishnan S, Gholamrezanezhad A. Coronavirus disease 2019 (COVID-19): a systematic review of imaging findings in 919 patients. Am J Roentgenol. 2020:1-7.

16. American College of Radiology. ACR recommendations for the use of chest radiography and computed tomography (CT) for suspected COVID-19 infection. ACR website. Advocacy-and Economics/ACR-Position-Statements/Recommenda tions-for-Chest-Radiography-and-CTfor-SuspectedCOVID19-Infection. Updated March. 2020 Mar $11 ; 22$.

17. Sohrabi C, Alsafi Z, O’Neill N, Khan M, Kerwan A, Al-Jabir A, Iosifidis C, Agha R. World Health Organization declares global emergency: A review of the 2019 novel coronavirus (COVID-19). Int J Surg. 2020.

18. Public Health England. Guidance on social distancing for everyone in the UK. Available at: https://www.unity-health.co.uk/covid-19information-for-patients/government-guidance-onsocial-distancing-for-everyone-in-the-uk-andprotecting-older-people-and-vulnerable-adults-2/. Accessed on 26 March 2020.

19. Centers for disease control and prevention (5 April 2020)-What to Do if You Are Sick. Archived from the original on 14 February 2020. Retrieved 24 April 2020.

20. World Health Organization (WHO)- When and how to use masks. Available at: https://www.who.int/emergencies/diseases/novelcoronavirus-2019/advice-for-public/when-and-howto-use-masks. Accessed on 24 April 2020.

21. Letko M, Marzi A, Munster V. Functional assessment of cell entry and receptor usage for SARS-CoV-2 and other lineage B betacoronaviruses. Nature Microbiol. 2020;5(4):562-9.

22. Zhang H, Penninger JM, Li Y, Zhong N, Slutsky AS. Angiotensin-converting enzyme 2 (ACE2) as a SARS-CoV-2 receptor: molecular mechanisms and potential therapeutic target. Intensive Care Med. 2020;46(4):586-90. 
23. Xu H, Zhong L, Deng J, Peng J, Dan H, Zeng X, et al. High expression of ACE2 receptor of 2019-nCoV on the epithelial cells of oral mucosa. Inter $\mathbf{J}$ Oral Sci. 2020;12(1):8.

24. Verdecchia P, Cavallini C, Angeli F. The pivotal link between ACE2 deficiency and SARS-COV2 infection. Eur J Intern Med. 2020.

25. Irani R, Xia Y. Renin angiotensin signalling in normal pregnancy and preeclampsia. Semin Nephrol. 2011;31(1):47-58.

26. Qiao J. What are the risks of COVID-19 infection in pregnant women? The Lancet. 2020;395(10226):760-2.

27. Day M. Covid-19: ibuprofen should not be used for managing symptoms, say doctors and scientists. BMJ. 368:m1086.

28. Tang N, Bai H, Chen X, Gong J, Li D, Sun Z. Anticoagulant treatment is associated with decreased mortality in severe coronavirus disease 2019 patients with coagulopathy. J Thromb Haemos. 2020;18(5):1094-9.

29. Murthy S, Gomersall CD, Fowler RA. Care for critically Ill patients with COVID-19. JAMA. 2020;323(15):1499.

30. World Health Organization. Clinical management of severe acute respiratory infection when novel coronavirus (2019-nCoV) infection is suspected: interim guidance. In Clinical management of severe acute respiratory infection when novel coronavirus (2019-nCoV) infection is suspected: Interim guidance; 2020:21-21.

31. Dong E, Du H, Gardner L. An interactive web-based dashboard to track COVID-19 in real time. The Lancet Infect Dis. 2020;20(5):533-4.
32. Wang M, Cao R, Zhang L, Yang X, Liu J, Xu M, et al. Remdesivir and chloroquine effectively inhibit the recently emerged novel coronavirus (2019-nCoV) in vitro. Cell Res. 2020;30(3):269-71.

33. Colson P, Rolain JM, Raoult D. Chloroquine for the 2019 novel coronavirus SARS-CoV-2. Int J Antimicrob Agents. 2020;55(3):105923.

34. Lu H. Drug treatment options for the 2019-new coronavirus (2019-nCoV). Biosci Trends. 2020;14(1):69-71.

35. Zhou N, Pan T, Zhang J, Li Q, Zhang X, Bai C. Glycopeptide antibiotics potently inhibit cathepsin $\mathrm{L}$ in the late endosome/lysosome and block the entry of Ebola virus, middle east respiratory syndrome coronavirus (MERS-CoV), and severe acute respiratory syndrome coronavirus (SARS-CoV). J Biol Chem. 2016;291:9218e32.

36. Colson P, Rolain JM, Lagier JC, Brouqui P, Raoult D. Chloroquine and hydroxychloroquine as available weapons to fight COVID-19. Int J Antimicrob Agents. 2020:105932.

37. Jin JM, Bai P, He W, Wu F, Liu XF, Han DM, et al. Gender differences in patients with COVID-19: Focus on severity and mortality. Frontiers Public Health. 2020;8:152.

Cite this article as: Nambiar SS, Ajith S, Reshmi VP. Covid 19, the Kerala experience: an observational, single centre retrospective study of outcome in covid positive pregnancies. Int J Reprod Contracept Obstet Gynecol 2020;9:3112-8. 